\title{
LOW MORTALITY RATE IN 97 CONSECUTIVE PANCREATICODUODENECTOMIES: the experience of a group
}

\author{
Paulo Roberto Ott FONTES ${ }^{1,2}$, Fábio Luiz WAECHTER ${ }^{1,2}$, Mauro NECTOUX ${ }^{1,2}$, \\ José Artur SAMPAI01, Uirá Fernandes TEIXEIRA ${ }^{1,2}$ and \\ Luiz PEREIRA-LIMA ${ }^{1,2}$
}

\begin{abstract}
Context - Pancreaticoduodenectomy is the procedure of choice for resectable cancer of the periampullary region. These tumors account for $4 \%$ of deaths from cancer, being referred to as one of the lowest survival rates at 5 years. Surgery remains a complex procedure with substantial morbidity and mortality. Despite reports of up to $30 \%$ mortality rates, in centers of excellence it have been identified as less than 5\%. Recent studies show that pancreaticojejunostomy represents the "Achilles' heel" of the procedure. Objective - To evaluate the post-operative 30 days morbidity and mortality rates. Methods - Retrospective analysis of 97 consecutive resected patients between July, 2000 and December, 2012. All patients were managed by the same group, and data were obtained from specific database service. The main objective was to evaluate the 30-day mortality rate, but we also studied data of surgical specimen, need for vascular resection and postoperative complications (gastric stasis, pancreatic fistula, pneumonia and reoperation rate). Results - Thirty-day mortality rate was $2.1 \%$ (two patients). Complete resection with no microscopic residual tumor was obtained in $93.8 \%$ of patients, and in $67.3 \%$ of cases pathology did not detected metastatic nodes. Among postoperative complications were reported $6 \%$ of prolonged gastric stasis, $10.3 \%$ of pneumonia, $10.3 \%$ of pancreatic fistula and $1 \%$ of infection in the drain pathway. Two patients underwent reoperation due to bleeding and infected hematoma caused by pancreatic fistula, and another for intestinal obstruction because of adhesions at postoperative day 12. Conclusion - The pancreaticoduodenectomy as treatment procedure for periampullary cancers has a low morbidity and mortality rate in services with experience in Hepato-Pancreato-Biliary surgery, remaining as first-line treatment in resectable patients.
\end{abstract}

HEADINGS - Pancreatic neoplasms. Pancreaticoduodenectomy. Mortality.

\section{INTRODUCTION}

Pancreaticoduodenectomy (PDT), described by Kausch in 1912 and popularized by Whipple in 1935, is considered one of the most complex operations of the digestive tract and remains the only treatment with possibility of cure for periampullary cancers ${ }^{(40)}$. Even providing a low cure rate, surgery has benefits on long-term survival ${ }^{(33)}$, with better results for neoplasms of the ampulla of Vater, duodenum and small distal cholangiocarcinomas, with less encouraging results for pancreatic neoplasms. Furthermore, the procedure is also utilized for benign lesions that may arise in periampullary area, including pancreatic cystic neoplasms, islet cell tumors, benign ampullary and duodenal adenomas and chronic pancreatitis ${ }^{(10)}$. This procedure is historically associated with high rates of postoperative morbidity and mortality, which has been decreasing in recent decades in centers specia- lized in Hepato-Pancreato-Biliary surgery with lots of surgeries per year, promoting chances of cure with acceptable complication rates ${ }^{(8,20,30)}$. This study aims to present the results of pancreaticoduodenectomies performed by the same Hepato-Pancreato-Biliary team, discussing important aspects of the management of these patients, emphasizing the first 30 days.

\section{METHODS}

We performed a retrospective analysis of 97 consecutive patients undergoing pancreaticoduodenectomy between July 2000 and December 2012 by the same Hepato-Pancreato-Biliary group at Federal University of Health Sciences of Porto Alegre (UFCSPA) - Santa Casa de Misericórdia Porto Alegre. The results were grouped according to the gender of the patient, presence of jaundice and preoperative serum albumin level. Enteral feeding through a nasoje-

Declared conflict of interest of all authors: non

${ }^{1}$ Universidade Federal de Ciências de Saúde de Porto Alegre, UFCSPA - Departamento de Clínica Cirúrgica; ${ }^{2}$ Serviço de Cirurgia Hepatobiliopancreática, Transplante Hepático e Pâncreas da Santa Casa de Porto Alegre - UFCSPA, RS, Brasil.

Correspondence: Uirá Fernandes Teixeira. Rua Gen. Vitorino 330, 802 - Centro - 90020-170 - Porto Alegre, RS, Brasil. E-mail: uiraft@yahoo.com.br 
junal tube (positioned during surgery) was initiated after the onset of bowel sounds, usually on the 3nd postoperative day, at low volume $(15-20 \mathrm{~mL} / \mathrm{h})$, being progressed as tolerated. All patients underwent Whipple operation with locoregional lymphadenectomy. The postoperative follow-up was performed by the surgical team and the results were analyzed using Epi-info software version 3.5.1. The main objective was to evaluate the 30-day mortality rate. Furthermore, we studied data of surgical specimen, need for vascular resection and postoperative complications (gastric stasis, pancreatic fistula, pneumonia and reoperation rate).

\section{RESULTS}

Fifty-six patients were men and forty-one women (Table 1), with mean age of 63.8+/- 13.5 years (29-84 years). Sixty-six $(68 \%)$ patients had jaundice at diagnosis, with a mean serum bilirubin $9.5+/-8.2 \mathrm{mg} / \mathrm{dL}(0.3$ to $39 \mathrm{mg} / \mathrm{dL})$ and serum albumin of $3.4+/-0.6 \mathrm{mg} / \mathrm{dL}$ ( 2.2 to $4.5 \mathrm{mg} / \mathrm{dL}$ ). The mean hospital stay was 15 days, ranging from 7 to 36 days, according to postoperative complications.

TABLE 1. Characteristics of the sample

\begin{tabular}{lc}
\hline Men & $57.7 \%$ \\
Preoperative jaundice & $68 \%$ \\
Age (years) & $63.8 \pm 13.5(29-84)$ \\
Total bilirubin $(\mathrm{mg} / \mathrm{dL})$ & $9.5 \pm 8.2(0,3-39)$ \\
Albumin $(\mathrm{mg} / \mathrm{dL})$ & $3.4 \pm 0.6(2,2-4,5)$ \\
Bleeding $(\mathrm{mL})$ & $376.6 \pm 179.1(100-1200)$ \\
Lesion size $(\mathrm{cm})$ & $3.5 \pm 1.7(1-8)$ \\
Vessel resection & $6.2 \%$ \\
Clear margins & $93.8 \%$ \\
\hline
\end{tabular}

In 94 patients, the reconstruction of the digestive tract was by pancreaticojejunostomy with internal stent (a thin fenestrated silicone tube), hepaticojejunostomy and gastrojejunostomy (end-to-side), in the classical way and in this order, as described by Child ${ }^{(11)}$. Three patients underwent pancreaticogastrostomy and Roux-en-Y hepaticojejunostomy.

Histology of surgical specimens are shown in Table 2.

TABLE 2. Histopathology

\begin{tabular}{lc}
\hline Pathology report & $\mathbf{n}(\%)$ \\
\hline Pancreatic adenocarcinoma & $58(59.8)$ \\
Ampullary adenocarcinoma & $15(15.5)$ \\
Distal cholangiocarcinoma & $6(6.2)$ \\
Duodenal adenocarcinoma & $3(3.1)$ \\
Cystadenocarcinoma of the pancreas & $3(3.1)$ \\
Chronic pancreatitis & $3(3.1)$ \\
Neuroendocrin tumor & $3(3.1)$ \\
Intraductal papillary mucinous neoplasm & $2(2.1)$ \\
Cystadenoma of the pancreas & $2(2.1)$ \\
Epidermoid carcinoma of the pancreas & $1(1)$ \\
Microcystic adenoma of the pancreas & $1(1)$ \\
\hline
\end{tabular}

The mean tumor size was $3.5+/-1.7 \mathrm{~cm}(1-8 \mathrm{~cm})$, with R0 resection in $91(93.8 \%)$ patients. Sixty-five $(67.3 \%)$ patients showed no metastatic spread to lymph nodes. The 30-day mortality rate was $2.1 \%$. Six patients required en bloc resection of pancreatic head cancer and portal/mesenteric veins. Of these, five $(83.3 \%)$ had metastatic disease to lymph nodes.

Among complications in postoperative period, we observed local and general ones. The former include prolonged gastric stasis in $6 \%$ and pancreatic fistula in 10.3\% (Table 3). One patient presented bleeding after pancreatic fistula on postoperative day 8 , needing surgical intervention. He died 11 days after in the intensive care unit (ICU), with multiple organ dysfunction. The other patient who died in our series developed and infected hematoma on postoperative day 12; he was re-operated but died after 3 days. One patient had infection in the path of the Penrose drain, located adjacent to the biliary anastomosis, and was treated with intravenous antibiotics.

TABLE 3. Significant postoperative morbidity

\begin{tabular}{lc}
\hline Local & \\
Gastric stasis & $6 \%$ \\
Pancreatic fistula & $10.3 \%$ \\
Drain path infection & $1 \%$ \\
\hline General & \\
Intestinal obstruction & $1 \%$ \\
Pneumonia & $10.3 \%$ \\
30-day mortality & $2.1 \%$ \\
\hline
\end{tabular}

Among general complications, we observed a 10.3\%-pneumonia rate. One patient required surgical intervention due to intestinal obstruction because of adhesions, and reoperation was performed on the 12th postoperative day, with good outcome.

Pancreatic fistula was generally treated by keeping the drain placed near the pancreatic anastomosis, and maintenance of enteral feeding through the nasojejunal tube, with mean spontaneous closure of 14 days (4-31 days). Three patients required total parenteral nutrition (TPN). One patient for whom relaparotomy was performed for postoperative haemorrhage, and the others that were treated with antibiotics, fasting and TPN for 5 and 8 days, respectively, with good outcome.

\section{DISCUSSION}

Mortality after PDT has decreased progressively. In the $70 \mathrm{~s}$, it was approximately $25 \% \%^{(2)}$, being referred currently as less than $5 \%{ }^{(27)}$. Some series show no mortality ${ }^{(2,10,13,34)}$. However, postoperative morbidity has not experienced the same decline, being around $30 \%-60 \%$ in recent reports ${ }^{(14,31,35,37,41)}$.

\section{Pancreatic fistula}

The most important cause of mortality and morbidity after PDT has been the fistula from pancreatic stump anas- 
tomosis $^{(2,3,26,35)}$, which remains today as the Achilles' heel of this procedure ${ }^{(12,15)}$, accounting for approximately one third of the postoperative complications ${ }^{(33)}$.

Study published by Topal et al. ${ }^{(35)}$ that analyzed 351 patients undergoing PDT showed that $12 \%$ had pancreatic fistula, with relevant mortality and re-operation rates, also strongly associated with other complications such as prolonged gastric stasis, evisceration and intra-abdominal abscess. In our series, $10(10.3 \%)$ patients had this postoperative complication, with the need of a new surgery in two of them. Both died after the procedure. In the other patients, clinical management was sufficient for good outcome. Other national series show similar results, reporting $9.7 \%$ pancreatic fistula rate ${ }^{(28)}$.

In a series of 2000 consecutive PDT ${ }^{(18)}$, the soft consistency of the pancreatic parenchyma was responsible for an incidence of $22.6 \%$ fistula rate. This would generate an increased risk of about 10 times compared with hardened or intermediate consistency glands. These results have been reproduced in other studies ${ }^{(5,9,23)}$. The diameter of the Wirsung duct less than $3 \mathrm{~mm}$ was also associated with a $22 \%$ rate of fistula, compared to $7 \%$ in ducts with a diameter greater than $3 \mathrm{~mm}^{(36)}$.

Currently, conservative treatment of pancreatic fistula is feasible in most cases, with maintenance of abdominal drains, percutaneous drainage, antibiotics and enteral/parenteral nutrition ${ }^{(3)}$. Nowadays, a small number of patients will require surgery, either to wash out the abdominal cavity in cases of peritonitis and to repositioning drains, or even to perform total pancreatectomy ${ }^{(36)}$.

The anastomosis of the jejunum to the pancreatic remnant and its variations of invagination, telescoping, "duct-to-mucosa", among others, remains the most widely used method for reconstruction ${ }^{(4,25,32,38)}$. Pancreatic stenting through pancreatic anastomosis after PDT has long been reported by many authors ${ }^{(1,24,29,42)}$. Some reasons supporting the usefulness of an internal stent are diverting the pancreatic enzymes from the pancreatic anastomotic area and to allow more precise placement of sutures during pancreatic anastomosis. However, there are lack of evidence that internal pancreatic duct stenting decreases the frequency or the severity of postoperative pancreatic fistulas ${ }^{(6,17,42)}$. Nevertheless, we still continue placing internal stents in pancreaticojejunal anastomosis during PDT.

The pancreaticogastrostomy is an alternative technique, referred by many authors as being easy to perform and with advantages due to the extensive intramural vascular network of the stomach wall, failure in the activation of pancreatic juice in the acidic environment of the gastric lumen and accessibility of the anastomosis site by endoscopy, among others ${ }^{(21,44)}$. In our series, in three patients the pancreatic anastomosis was performed with the gastric remnant, with a favorable outcome.

\section{Prolonged gastric stasis}

Postgastrectomy syndrome that occurs after PDT, characterized by nausea, vomiting, diarrhea and dyspepsia, is a common complication in the postoperative period, with series reporting its incidence in up to $60 \%{ }^{(16,19,39)}$. The pathophysiology is still poorly understood, but mechanical obstruction and reversible causes (abnormalities in serum electrolytes, poor glycemic control, use of narcotics and pain, among others) should be investigated and corrected before confirming this hypothesis. It is postulated that the removal of the duodenum would be responsible for the decrease in serum $\operatorname{motilin}^{(19)}$, responsible for stimulating the migratory motor complex of the gastrointestinal tract. This hypothesis is supported by the positive results after the use of a motilin agonist in low doses, the macrolide antibiotic erythromy$\operatorname{cin}^{(19,22)}$, which has been reported as a reduction factor of up to $37 \%$ in the incidence of gastroparesis. However, in daily practice, the symptoms caused by delayed gastric emptying can be improved by the use of prokinetic drugs, such as bromopride or metoclopramide.

Independent risk factors for the occurrence of prolonged gastric stasis are intra-abdominal complications such as pancreatic fistula and abscess, whose incidence grows proportionally to the severity of these complications ${ }^{(19)}$. Finally, the prolonged gastric stasis is not usually a serious complication with mortality risk, but can cause discomfort, increase the length of hospital stay, hospital costs, and reduce the quality of life postoperatively. It is our opinion that many of the labeled post-PDT gastroparesis are due to some technical fault in the manufacture of gastroenterostomy, such as angled anastomoses and/or with small diameter. Although it has been reported that pylorus-preserving PDT (PPPDT) and classical Whipple's PDT are equal operations regarding postoperative development of prolonged gastric $\operatorname{stasis}^{(10,19)}$, we believe that devascularization and denervation of the pylorus with subsequent pylorospasm in PPPDT may contribute to delayed gastric emptying.

\section{R0 resection and vascular resection}

Complete tumor resection is associated with prolonged survival. Resections involving microscopic (R1) or macroscopic (R2) positive margins are reported in about $14 \%-40 \%$ of patients and are associated with significantly worsened long-term results when evaluated by multivariate analysis ${ }^{(7,43)}$. A review of 12,101 patients published by Bilimoria et al. ${ }^{(7)}$ showed that margin involvement was observed in $24.4 \%$ of cases (14.6\% microscopic and macroscopic $9.8 \%$ ); to undergo surgery at low-volume centers (less than 7 resections/year) gives $21 \%$ more chance of getting positive margins (OR 1.21, $95 \% \mathrm{CI}, 1.01$ to 1.43 ).

To achieve the goal of $\mathrm{R} 0$ resection is often necessary to resect a segment of the vessel adjacent to the neoplastic process. In six patients in this series, we performed resection of portal-mesenteric wall, all reaching the goal of presenting free margins. Vascular resections are complex procedures, which increase morbidity and mortality and should only be performed by experienced surgeons.

\section{Final considerations}

We believe that the critical point for the low early mortal- 
ity rate is the surgical team expertise in this operation. The systematization of the surgical technique, together with the growing volume of patients in recent years (in 2012, 12 patients were operated), enables greater familiarity with all the details that involve pre, intra and post-operative period, and culminate in satisfactory outcome.

The knowledge of the surgical anatomy and its variations, and the familiarity with complex procedures such as vascular sutures and use of prostheses, reduces intraoperative bleeding and makes the procedure faster. The careful preparation of pancreatojejunostomy with good vascularization and tension-free is of great significance, since pancreatic fistula and its consequences are the main responsible for the morbidity and mortality in these patients. This was responsible for the two deaths that occurred in our series.

It is worth remembering that improved intraoperative anesthetic care and intensive care unit staff postoperatively are important factors to achieve good outcomes.

This is a retrospective study, with all the limitations related to this design. However, as we use laboratory data and results of pathological study stored in the computer system of our institution, as well as surgical descriptions, there were no major difficulty in data collection. Furthermore, because we are analyzing early mortality rate, there was no loss of follow up, since even patients who were discharged before the first 30 days had at least one consultation for surgical review.

\section{CONCLUSION}

Pancreaticoduodenectomy remains a complex surgery, influenced by several variables related to the patient and the surgical team. Without doubt, it is possible to reduce the morbidity and mortality related to the procedure when it is performed by skilled teams in high-volume centers and specialized in Hepato-Pancreato-Biliary surgery. The technical refinement of surgeons, allied to technological advances, anesthesiology and improved postoperative care, are able to provide adequate support and improve clinical outcome, achieving similar results of the centers of excellence.

Fontes PRO, Waechter FL, Nectoux M, Sampaio JA, Teixeira UF, Pereira-Lima L. Baixa mortalidade em 97 duodenopancreatectomias consecutivas: a experiência de um grupo. Arq Gastroenterol. 2014,51(1):29-33.

RESUMO - Contexto - A duodenopancreatectomia é o procedimento de escolha para neoplasias ressecáveis da região periampolar. Estes tumores representam $4 \%$ dos óbitos por câncer, sendo referida como uma das mais baixas taxas de sobrevida em 5 anos. A cirurgia continua sendo um procedimento complexo com substancial morbi-mortalidade. Apesar dos relatos de até 30\% de mortalidade, em serviços de excelência tem sido apontada como inferior a $5 \%$ e estudos recentes mostram que a pancreatojejunostomia representa o "tendão de Aquiles" do procedimento. Objetivo - Avaliar a morbi-mortalidade em 30 dias nesta série de pacientes ressecados. Métodos - Analisamos até o momento dados de 97 pacientes consecutivos submetidos à duodenopancreatectomia de julho de 2000 a dezembro de 2012. Todos os pacientes foram manejados pelo mesmo grupo e os dados obtidos de banco de dados específico do serviço. O objetivo principal era avaliar a mortalidade em 30 dias, mas também foi reportado os dados referentes ao espécime cirúrgico, a necessidade de ressecção vascular e complicações pós-operatórias (estase gástrica, fístula pancreática, pneumonia e taxa de reoperação). Resultados - A mortalidade em 30 dias foi 2.1\% (dois pacientes). Em $93.8 \%$ dos pacientes a ressecção foi completa com margem microscópica tumoral negativa e em $67.3 \%$ dos casos não se detectou linfonodos metastáticos ao estudo anatomopatológico. Entre as complicações pós-operatórias, foram relatadas $6 \%$ de estase gástrica prolongada, $10.3 \%$ de pneumonia, $10.3 \%$ de fístula pancreática e $1 \%$ de infecção no trajeto do dreno. Dois pacientes foram submetidos a reoperação devido a sangramento e hematoma infectado decorrente de fístula pancreática. Um paciente foi reoperado por obstrução intestinal por brida no $12^{\circ}$ dia de pós-operatório. Conclusão - A duodenopancreatectomia como tratamento das neoplasias periampolares é procedimento de baixa morbi-mortalidade em serviços com experiência em cirurgia hepatobiliopancreática, permanecendo como tratamento de primeira linha em pacientes ressecáveis.

DESCRITORES - Neoplasias pancreáticas. Pancreaticoduodenectomia. Mortalidade. 


\section{REFERENCES}

1. Ammori BJ, White CM. Proximal migration of transanastomotic pancreatic stent following pancreaticoduodenectomy and pancreaticojejunostomy. Int $\mathbf{J}$ Pancreatol. 1999;25:211-5.

2. Aranha GV, Hodul PJ, Creech S, Jacobs W. Zero mortality after 152 consecutive pancreaticoduodenectomies with pancreaticogastrostomy. J Am Coll Surg. 2003;197:223-31.

3. Bassi C, Dervenis C, Butturini G, Fingerhut A, Yeo C, Izbicki J, Neoptolemos J, Sarr M, Traverso W, Buchler M; International Study Group on Pancreatic Fistula Definition. International Study Group on Pancreatic Fistula Definition Postoperative pancreatic fistula: an international study group (ISGPF) definition. Surgery. 2005;138:8-13

4. Bassi C, Falconi M, Molinari E, Mantovani W, Butturini G, Gumbs AA, Salvia R, Pederzoli P. Ducto-mucosa versus end-to-side pancreaticojejunostomy reconstruction after pancreaticoduodenectomy: results of a prospective randomized trial. Surgery. 2003;134:766-71.

5. Berger AC, Howard TJ, KennedyEP, Sauter PK, Bower-Cherry M, Dutkevitch S, Hyslop T, Schmidt M, Rosato EL, Lavu H, Nakeeb A, Pitt HA, Lillemoe KD, Yeo CJ. Does Type of Pancreaticojejunostomy after Pancreaticoduodenectomy Decrease Rate of Pancreatic Fistula? A Randomized, Prospective, Dual-Institution Trial. J Am Coll Surg. 2009;208:738-47.

6. Biffl WL, Moore EE. Pancreaticojejunal stent migration resulting in "bezoar ileus". Am J Surg. 2000;180:115-6.

7. Bilimoria KY, Talamonti MS, Sener SF, Bilimoria MM, Stewart AK, Winchester DP, Ko CY, Bentrem DJ. Effect of hospital volume on margin status after pancreaticoduodenectomy for cancer. J Am Coll Surg. 2008;207:510-9.

8. Birkmeyer JD, Finlayson SRG, Tosteson ANA, Sharp SM, Warshaw AL, Fisher ES. Effect of hospital volume on in-hospital mortality with pancreaticoduodenectomy. Surgery. 1999;125:250-6.

9. Callery MP, Pratt WB, Vollmer CM. Prevention and management of pancreatic fistula. J Gastrointestinal Surg. 2008.

10. Cameron JL, Pitt HA, Yeo CJ, Lillemoe KD, Kaufman HS, Coleman J. One hundred and forty-five consecutives pancreaticoduodenectomies without mortality. Ann Surg 1993; 217:430-8.

11. Child CG, Ellis JT. Radical pancreaticoduodenectomy: report of two autopsies performed five and four years after operation. Ann Surg. 1951;134:80-87.

12. Erdmann J, van Eijick CHJ, Jeekel J. Standart resection of pancreatic cancer and chance of cure. Am J Surg. 2007;194:S104-9

13. Kazanjian KK, Hines OJ, Duffy JP, Yoon DY, Cortina G, Reber HA. Improved survival following pancreaticoduodenectomy to treat adenocarcinoma of the pancreas - the influence of operative blood loss. Arch Surg. 2008;143:1166-71.

14. Kimura W. Strategies for the treatment of invasive ductal carcinoma of the pancreas and how to achieve zero mortality for pancreaticoduodenectomy. $\mathbf{J}$ Hepatobiliary Pancreat Surg. 2008;15:270-7.

15. Kleepies A, Albermeister M, Obeidat F, Seeliger H, Jauch KW, Bruns CJ. The challenge of pancreatic anastomosis. Langerbecks Arch Surg. 2008; 393:459-71.

16. Leung J, Silverman W. Diagnostic and therapeutic approach to pancreatic cancer-associated gastroparesis. Dig Dis Sci. 2009;54:401-5.

17. Levy MJ, Chari S, Adler DG, Clain JE, Gostout CJ, Harewood GC, Pearson RK, Petersen BT, Sarr MJ, Farnell MB. Complications of temporary pancreatic stent insertion for pancreaticojejunal anastomosis during pancreaticoduodenectomy. Gastrointest Endosc 2004;59:719-24.

18. Lin JW, Cameron JL, Yeo CJ, Riall TS, Lillemoe KD. Risk factors and outcomes in postpancreaticoduodenectomy pancreaticocutaneos fistula. J Gastrointest Surg. 2004;8:951-9.

19. Lytras D, Paraskevas KI, Avgerinos C, Manes C, Touloumis Z, Paraskeva KD, Dervernis C. Therapeutic strategies for the management of delayed gastric emptying after pancreatic resection. Langerbecks Arch Surg. 2007;392:1-12.

20. Luft S, Hunt SS, Maerki SC. The volume-outcome relationship: practice-makesperfect or selective-referral patterns? Health Serv Res. 1987;22:157-82.

21. McKay A, Mackenzie S, Sutherland FR, Bathe OF, Doig C, Dort CJ, Vollmer CM, Dixon E. Meta-analysis of pancreaticojejunostomy versus pancreaticogastrostomy reconstruction after pancreaticoduodenectomy. Br J Surg. 2006;93:929-6.

22. Ohwada S, Satoh Y, Kawate S, Yamada T, Kawamura O, Koyama T, YoshimuraS Tomizawa N, Ogawa T, Morishita Y. Low-Dose Erythromycin Reduces Delayed Gastric Emptying and Improves Gastric Motility After Billroth I Pylorus-Preserving Pancreaticoduodenectomy. Ann Surg. 2001;234:668-74.

23. Pereira FL, Vasques FT, Moricz AD, Campos TD, Pacheco AM Jr, Silva RA. Correlation analysis between post-pancreatoduodenectomy pancreatic fistula and pancreatic histology. Rev Col Bras Cir. 2012;39:41-7.
24. Poon RTP, Fan ST, Lo CM, Yuen WK, Yeung C, Wong J. External Drainage of Pancreatic Duct With a Stent to Reduce Leakage Rate of Pancreaticojejunostomy After Pancreaticoduodenectomy: A ProspectiveRandomized Trial. Ann Surg. 2007;246:425-35

25. Poon RTP, Fan STF. Decreasing the pancreatic leak rate after pancreaticoduodenectomy. Adv Surg. 2008;42:33-48.

26. Rezvani M, O'Moore PV, Pezzi CM. Late pancreaticojejunostomy stent migration and hepatic abscess after Whipple procedure. J Surg Educ. 2007;64:220-3.

27. Riall TS, Nealon WH, Goodwin JS, Zhang D, Kuo YF, Townsend CM, Freeman JL. Pancreatic cancer in the general population: improvements in survival over the last decade. J Gastroint Surg. 2006;10:121224.

28. Rocha LCG, Queiroz FL, Magalhães EA, Santos FAV, Caldeira DAM, Ribas MA. Duodenopancreatectomia: avaliação dos resultados em 41 pacientes. Rev Col Bras Cir. 2006;33:387-92.

29. Roder JD, Stein HJ, Böttcher KA, Busch R, Heidecke CD, Siewert JR. Stented versus nonstented pancreaticojejunostomy after pancreatoduodenectomy: a prospective study. Ann Surg. 1999;229:41-8

30. Satoi S, Toyokawa H, Yanagimoto H, Yamamoto T, Yamao J, Kim S, Matsui Y, Takai S, Mergental H, Kamiyama Y. A New Guideline to Reduce Postoperative Morbidity After Pancreaticoduodenectomy. Pancreas. 2008;37:128-33.

31. Sewnath ME, Karsten TM, Prins MH, Rauws EJA, Obertop H, Gouma DJ. A Meta-analysis on the Efficacy of Preoperative Biliary Drainage for Tumors Causing Obstructive Jaundice. Ann Surg. 2002;236:17-27.

32. Shrikhande SV, Qureshi SS, Rajneesh N, Shukla P. Pancreatic Anastomoses after Pancreaticoduodenectomy: Do We Need Further Studies? World J Surg 2005;29:1642-9.

33. Siriwardana HPP, Siriwardena AK. Systematic review of outcome of synchronous portal-superior mesenteric vein resection during pancreatectomy for cancer. Br J Surg. 2006;93:662-73.

34. Suzuki Y, Fujino Y, Ajiki T, Ueda T, Sakai T, Tanioka Y, Kuroda Y. No Mortality among 100 Consecutive pancreaticoduodenectomies in a Middle-volume Center. World J Surg. 2005;29:1409-14.

35. Topal B, Aerts R, Hendrickx T, Fieuws S, Penninckx F. Determinants of complications in pancreaticoduodenectomy. EJSO. 2007;33:488-92.

36. van Berge Henegouven MI, De Wit LT, Van Gulik TM, Obertop H, Gouma DJ. Incidence, risk factors and treatment of pancreatic leakage after pancreaticoduodenectomy: drainage versus resection of the pancreatic remnant. J Am Coll Surg. 1997; 185:18-24

37. Wang Q, Gurusamy KS, Lin H, Xie X, Wang C. Preoperative biliary drainage for obstructive jaundice. Cochrane Database Syst Rev. 2008;(3):CD005444.

38. Watanabe M, Usui S, Kajiwara H, Nakamura M, Sumiyama Y, Takada T, Nagakawa T. Current pancreatogastrointestinal anastomotic methods: results of a Japanese survey of 3109 patients. J Hepatobiliary Pancreat Surg. 2004;11:25-33.

39. Wente MN, Bassi C, Dervenis C, Fingerhut A, Gouma DJ, Izbicki JR, Neoptolemos JP, Padbury RT, Sarr MG, Traverso W, Yeo CJ, Buchler MW. Delayed gastric emptying (DGE) after pancreatic surgery: a suggested definition by the International Study Group of Pancreatic Surgery (ISGPS). Surgery. 2007;142:761-7.

40. Winter JM, Cameron JL, Campbell KA, Arnold MA, Chang DC, Coleman J, Hodgin MB, Sauter PK, Hruban RH, Riall TS, Schulick RD, Choti MA, Lillemoe KD, Yeo CJ. 1423 pancreaticoduodenectomies for pancreatic cancer: a single institution experience. J Gastroint Surg. 2006;10:1199-211.

41. Winter JM, Cameron JL, Yeo CJ, Alao B, Lillemore KD, Campbell KA, Schulik RD. Biochemical markers predict morbidity and mortality after pancreaticoduodenectomy. J Am Coll Surg. 2007;204:1029-36; discussion 1037-8.

42. Winter JM, Cameron JL, Campbell KA, Chang DC, Riall TS, Schulick RD, Choti MA, Coleman J, Hodgin MB, Sauter PK, Sonnenday CJ, Wolfgang CL, Marohn $\mathrm{MR}$, Yeo CJ. Does pancreatic duct stenting decrease the rate of pancreatic fistula following pancreaticoduodenectomy? Results of a prospective randomized trial. J Gastrointest Surg. 2006;10:1280-90.

43. Yekebas EF, Bogoevski D, Cataldegirmen G, Kunze C, Marx A, Vashist YK, Schurr PG, Liebl L, Thieltges S, Gawad KA, Schneider C, Izbicki JR. Em bloc vascular resection for locally advanced pancreatic malignancies infiltrating major blood vessels: perioperative outcome and long-term survival in 136 patients. Ann Surg. 2008;247:300-9.

44. Yeo CJ, Cameron JL, Maher MM, Sauter PK, Zahurak ML, Talamini MA, Lillemoe KD, Pitt HA. A prospective randomized trial of pancreaticogastrostomy versus pancreaticojejunostomy after pancreaticoduodenectomy. Ann Surg. 1995;222:580-92. 